VioletTA RoDEK

ORCID 0000-0002-2501-4092

Uniwersytet Śląski w Katowicach

\title{
POCZUCIE WŁASNEJ SKUTECZNOŚCI JAKO CZYNNIK RÓŻNICUJĄCY SAMODZIELNE UCZENIE SIĘ STUDENTÓW
}

\begin{abstract}
AвstRact. Rodek Violetta, Poczucie własnej skuteczności jako czynnik różnicujacy samodzielne uczenie się studentów [The Feeling of self-Efficacy as a Factor Differentiating Students' Independent Learning]. Studia Edukacyjne nr 58, 2020, Poznań 2020, pp. 107-122. Adam Mickiewicz University Press. ISSN 1233-6688. DOI: $10.14746 /$ se.2020.58.6
\end{abstract}

The article presents empirical and diagnostic research aiming to recognise how a generalised feeling of self-efficacy differentiates students' independent learning. In the research, Generalized Self - Efficacy Scale (GSES) was applied (according to R. Schwarzer, M. Jeruzalem, in the Polish adaptation by Z. Juczyński) as well as a free-form interview, partially categorised. The study group was composed of 215 intentionally selected pedagogy students, following full-time and part-time courses. The variable adopted in the research differentiates the view of students' independent learning, mainly in terms of the degree of involvement in their own learning. A high level of self-efficacy seems to be related to regularity, persistence in learning, consistency, the ability to focus on longer periods of learning, as well as the ability to plan and organize one's own learning process. A generalized sense of self-efficacy, however, is not critical to how we understand the concept of learning, assigning value to it, and the used learning techniques.

Key words: self-efficacy, independent learning

Poczucie własnej skuteczności, zgodnie z założeniami teorii społeczno-poznawczej, wchodzi w zakres kontroli osobistego działania. Można je rozumieć jako przekonanie o własnych zdolnościach i możliwościach działania dla osiągnięcia wybranego celu bez względu na pojawiające się przeszkody ${ }^{1}$. Przekonanie to i oczekiwania z nim związane są względnie trwałe,

${ }^{1}$ A. Bandura, Self-efficacy. Toward a Unifying Theory of Behavioral Change, Psychological Review, 1977, 2, s. 191-215; tenże, Teoria społecznego uczenia się, Warszawa 2007, s. 17-18. Zob. także: Z. Juczyński, Poczucie własnej skuteczności - teoria i pomiar, Acta Universitatis Lodziensis Folia Psychologica, 2000, 4, s. 11-24. 
kształtują się $\mathrm{w}$ trakcie rozwoju oraz różnicują ludzi pod względem myślenia, odczuwania i działania. Poczucie własnej skuteczności wpływa na wybór celów życiowych - im wyższy jego wskaźnik, tym jednostka stawia sobie ambitniejsze cele oraz silniej angażuje się w zamierzone zachowanie, nawet w obliczu przeszkód i piętrzących się porażek². Wraz ze wzrostem przekonania, że jest się w stanie rozwiązać określony problem, wzrasta poziom motywacji do działania w celu jego rozwiązania. Własna skuteczność ma znaczenie dla zmiany zachowań, gdyż umożliwia właściwą ocenę sytuacji oraz poszukiwanie skutecznego sposobu radzenia sobie w obliczu napotkanych trudności i przeszkód, które mogą osłabiać motywację ${ }^{3}$. Dotyczy to również intencji zmiany zachowań ryzykownych ${ }^{4}$. Wykazano, że poczucie własnej skuteczności pozwala przewidywać intencje i działania w różnych obszarach ludzkiej aktywności. Zwłaszcza w obszarze zachowań zdrowotnych prowadzono wiele badań w tym zakresie ${ }^{5}$. Dla dydaktyki szczególne znaczenie mają rezultaty analiz, wskazujące na wpływ silnego poczucia własnej skuteczności na procesy poznawcze i osiągnięcia intelektualne człowieka ${ }^{6}$, brakuje jednak szerszych badań o charakterze pedagogicznym czy interdyscyplinarnym, podejmujących ten wątek rozważań. Niniejszy artykuł prezentuje badania, w których próbowano rozpoznać, w jaki sposób uogólnione poczucie własnej skuteczności różnicuje samodzielne uczenie się studentów, pod względem przypisywania wartości uczeniu się, stosowanych technik samodzielnego uczenia się, stopnia zaangażowania $\mathrm{w}$ naukę własną oraz subiektywnego przeświadczenia o poziomie jej efektywności. Badania miały charakter diagnostyczny, opisow ${ }^{7}$ i zmierzały do dokonania opisu pewnych zjawisk oraz sytuacji, związanych z samodzielnym uczeniem się studentów, a zatem nie zachodziła potrzeba przyjmowania ścisłych twierdzeń i hipotez, charakterystycznych dla badań weryfikacyjnych ${ }^{8}$. Pytanie dotyczące różnicowania badanej populacji z uwzględnieniem zmiennej:

2 E.A. Locke, G.P. Latham, A theory of goal setting and task performance, New York 1990. Zob. także N. Ogińska-Bulik, Z. Juczyński, Osobowość, stres a zdrowie, Warszawa 2008.

${ }^{3}$ G. Dolińska-Zygmunt, Podmiotowe uwarunkowania zachowań promujacych zdrowie, Warszawa 2000. Por. J.E. Maddux, J. Lewis, Self-efficacy and adjustment. Basic principles and issues, [w:] Self-efficacy, adaptation and adjustment: theory, research and application, red. J.E. Maddux, New York 1995, s. 37-68.

${ }^{4}$ K. Lewtak, J. Smolińska, Uogólnione poczucie własnej skuteczności a zachowania antyzdrowotne lekarzy rodzinnych na przykładzie palenia tytoniu, Przegląd Epidemiologiczny, 2011, 65, s. 115-121.

${ }^{5}$ Przeglądu badań w tym zakresie dokonał Z. Juczyński (Z. Juczyński, Poczucie własnej skuteczności, s. 12-14).

${ }^{6}$ R. Schwarzer, R. Fuchs, Self-efficacy and Health Behaviours, [w:] Predicting Health Behaviour, red. M. Conner, P. Norman, Buckingham - Philadelphia 1996, s. 163-196.

${ }^{7}$ S. Palka, Metodologia. Badania. Praktyka pedagogiczna, Gdańsk 2006, s. 97-102.

${ }^{8}$ Zob. np. K. Rubacha, Metodologia badań nad edukacja, Warszawa 2008, s. 99, 102. 
uogólnione poczucie własnej skuteczności uznano za element eksploracji i diagnozy, a nie weryfikacji.

$\mathrm{W}$ badaniach zastosowano metodę skalowania oraz metodę wywiadu. Do ustalenia poczucia własnej skuteczności użyto Skali Uogólnionej Własnej Skuteczności (Generalized Self - Efficacy Scale - GSES) według R. Schwarzera i M. Jeruzalem, w polskiej adaptacji Z. Juczyńskiego" ${ }^{9}$, która nawiązując do sformułowanych przez A. Bandurę koncepcji oczekiwań i pojęcia spostrzeganej własnej skuteczności, mierzy siłę ogólnych przekonań jednostki na temat skuteczności radzenia sobie z trudnymi sytuacjami i przeszkodami. Dla rozpoznania przebiegu samodzielnego uczenia się studentów wykorzystano metodę wywiadu swobodnego, częściowo skategoryzowanego, o charakterze jawnym i indywidualnym ${ }^{10}$. Do jego przeprowadzenia posłużono się kwestionariuszem wywiadu, który zawierał większość pytań otwartych, zachęcających do swobodnego opisywania swoich doświadczeń, tworzenia własnych definicji, ujawniania opinii i postaw. Wszyscy respondenci zostali zapewnieni o poufności badań i ich pełnej anonimowości oraz wyrazili zgodę na przeprowadzenie wywiadu i jego rejestrowanie za pomocą dyktafonu. W dalszej kolejności dokonano transkrypcji nagranych wywiadów. Dzięki przeprowadzonym wywiadom uzyskano cenne dla realizacji celów badań informacje. Dodatkowo, pozwoliły one na usytuowanie przebiegu samodzielnego uczenia się studentów w szerszym kontekście, na przykład związanym z czynnikami zewnętrznymi warunkującymi ten proces. W niniejszym artykule, ze względów formalnych, skupiono się na analizie i prezentacji tylko niektórych wątków, podjętych przez respondentów.

W badaniach uczestniczyło 215 studentów drugiego roku pedagogiki, realizujących studia na Uniwersytecie Śląskim w Katowicach, w trybie dziennym - $67 \%$ osób badanych oraz zaocznym - 33\% uczestników badań. Zdecydowaną większość grupy badawczej - 93,5\% stanowiły kobiety, co z pewnością wiąże się ze specyfiką kierunku studiów. Dobór próby miał charakter celowy, a zatem uzyskanych wyników nie można uogólniać na całość populacji studentów. Ustalenie poziomu poczucia własnej skuteczności oraz identyfikacja problemów, związanych z samodzielnym uczeniem się w grupie osób studiujących pedagogikę, wydaje się mieć zasadnicze znaczenie w kontekście wymogu ustawicznego uczenia się oraz przyjęcia odpowiedzialności za przygotowanie przyszłych podopiecznych do tego procesu. Na podjęcie decyzji o przeprowadzeniu badań na terenie Uniwersytetu Śląskiego

${ }^{9}$ Zob. Z. Juczyński, Skala Uogólnionej Własnej Skuteczności, Warszawa 2009; tenże, Poczucie własnej skuteczności, s. 11-24.

${ }_{10}$ Zob. np. M. Łobocki, Metody i techniki badań pedagogicznych, Kraków 2005, s. 266-267; S. Juszczyk, Badania ilościowe w naukach społecznych. Szkice metodologiczne, Katowice 2005, s. 83-86. 
wpłynęły głównie względy ekonomiczne, a także dostępność potencjalnych uczestników badań ${ }^{11}$.

Badania były realizowane w semestrze letnim 2019 roku, przed sesją egzaminacyjną oraz we wrześniu tego samego roku, w sesji poprawkowej i przebiegały $\mathrm{w}$ dwóch etapach. Pierwszy polegał na ustaleniu poziomu poczucia własnej skuteczności badanych studentów za pomocą opisanego wcześniej arkusza skali. Wyniki były kodowane. Na ich podstawie możliwe stało się wyłonienie osób różniących się zdecydowanie pod względem poziomu poczucia własnej skuteczności i przeprowadzenie z nimi indywidualnych wywiadów.

W dalszej części artykułu przedstawiono uzyskane w badaniach wyniki, dotyczące - w pierwszej kolejności - postrzegania własnej skuteczności przez studentów pedagogiki, realizujących studia $\mathrm{w}$ trybie stacjonarnym i niestacjonarnym.

\section{Postrzeganie własnej skuteczności przez badanych studentów pedagogiki}

Do pomiaru poziomu poczucia własnej skuteczności uczestników badań wykorzystano wspomnianą już Skalę Uogólnionej Własnej Skuteczności (Generalized Self - Efficacy Scale - GSES) według R. Schwarzera i M. Jeruzalem, w polskiej adaptacji Z. Juczyńskiego ${ }^{12}$. Arkusz skali składał się z 10 tez, do których badana osoba miała możliwość ustosunkować się, wybierając i zaznaczając jedną z czterech możliwych odpowiedzi: tak - 4 punkty; raczej tak - 3 punkty; raczej nie - 2 punkty i nie - 1 punkt. Suma wszystkich ocen dała ogólny wskaźnik poczucia własnej skuteczności, który mieści się w granicach od 10 do 40 punktów. Im wyższy wskaźnik, tym większe poczucie własnej skuteczności. W prezentowanych badaniach uzyskane wyniki surowe wyrażono w skali stenowej, według której wyniki z przedziału 1-4 sten były traktowane jako niskie, z przedziału 5-6 jako przeciętne, a z przedziału 7-10 jako wysokie $^{13}$. Na rycinie 1 przedstawiono poziom poczucia własnej skuteczności wszystkich badanych studentów.

${ }^{11}$ Obecnie w opracowaniu znajduje się projekt szerszych badań o charakterze porównawczym, dotyczących samodzielnego uczenia się studentów.

12 Z. Juczyński, Skala Uogólnionej Własnej Skuteczności; tenże, Poczucie własnej skuteczności, s. 11-24. W pedagogicznej literaturze przedmiotu funkcjonuje też Test Poczucia Skuteczności autorstwa M. Chomczyńskiej-Rubachy i K. Rubachy (M. Chomczyńska-Rubacha, K. Rubacha, Test Poczucia Skuteczności. Opracowanie teoretyczne i psychometryczne Pracowni Narzędzi Badawczych Komitetu Nauk Pedagogicznych PAN, Przegląd Badań Edukacyjnych, 2013, 1, 16, s. 85-105).

${ }^{13}$ Z. Juczyński, Poczucie własnej skuteczności, s. 18. 


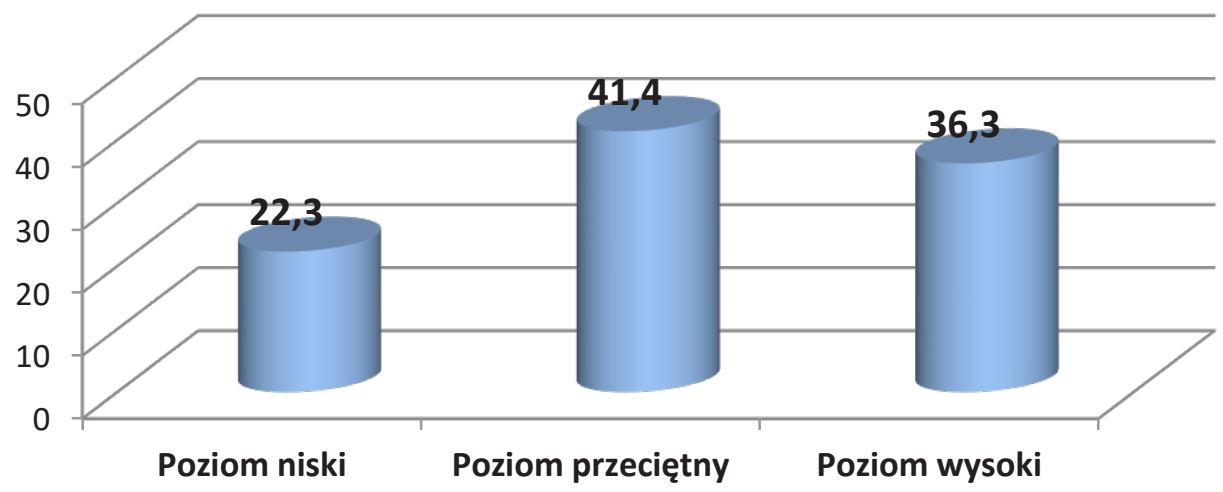

Dane dla N = 215 badanych studentów

Ryc. 1. Uogólnione poczucie własnej skuteczności studentów pedagogiki (źródło: badania własne: Generalized Self-Efficacy Scale - GSES)

Poziom poczucia własnej skuteczności studentów okazał się zróżnicowany, z niewielką przewagą wyniku średniego. Należy jednak zauważyć, że całkiem spory odsetek badanych charakteryzuje słabe przeświadczenie o własnej skuteczności. Podobny rozkład wyników uzyskano porównując poziom poczucia własnej skuteczności studentów studiów stacjonarnych i niestacjonarnych - rycina 2.

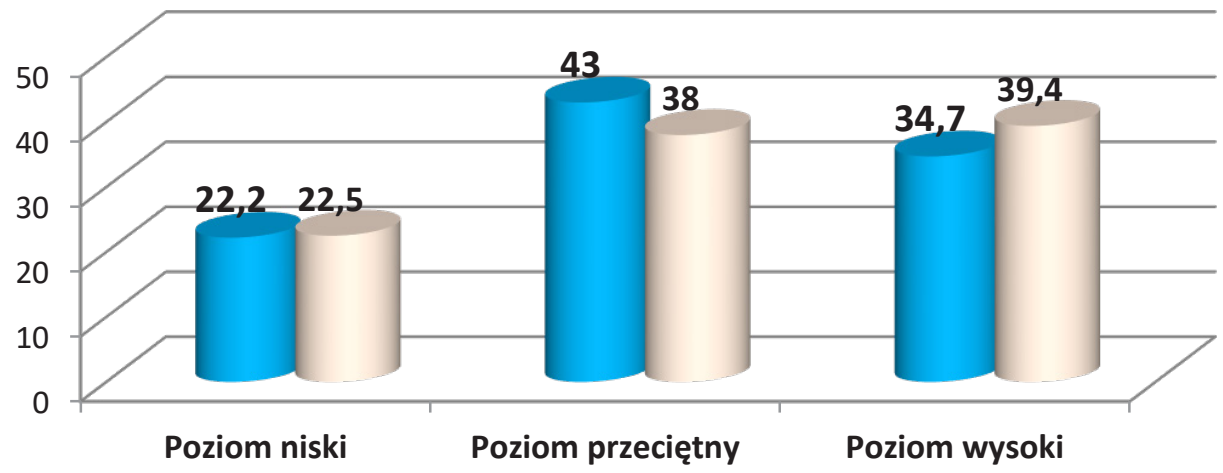

Dane dla N = 144 studentów studiów dziennych i N = 71 studentów studiów zaocznych

Ryc. 2. Uogólnione poczucie własnej skuteczności studentów studiów dziennych i zaocznych (źródło: badania własne: Generalized Self-Efficacy Scale - GSES) 
Jak wynika z danych zamieszczonych na rycinie 2, nieco wyższy odsetek studentów realizujących studia $\mathrm{w}$ trybie niestacjonarnym, $\mathrm{w}$ porównaniu ze studentami studiów dziennych, odznacza się wysokim poziomem poczucia własnej skuteczności. Różnice we wskaźnikach procentowych okazały się jednak niewielkie, zwłaszcza w przypadku poziomu niskiego. Nie zaobserwowano zatem znaczących różnic pomiędzy porównywanymi grupami. W obu dominuje przeciętny oraz wysoki poziom poczucia własnej skuteczności. Osoby przekonane o swoich zdolnościach wierzą, że poradzą sobie w konkretnej sytuacji i osiągną zamierzone, bardziej ambitne cele oraz silniej angażują się $\mathrm{w}$ ich urzeczywistnianie $\mathrm{e}^{14}$. W kontekście realizowanych celów badań należy zauważyć, że silne poczucie kompetencji może wpływać na procesy poznawcze i osiągnięcia intelektualne, skłaniać do zainwestowania większego wysiłku i wytrwałości oraz do wyboru bardziej ambitnych zadań $\mathrm{w}$ procesie uczenia się. $Z$ kolei, osoby o niskim poczuciu własnej skuteczności (w niniejszych badaniach stanowiły one ponad 22\% badanej populacji) wykazują zazwyczaj niskie aspiracje i słabe zaangażowanie w osiąganie założonych celów, w tym edukacyjnych. Podejmując się realizacji trudnych zadań, częściej rozpamiętują swoje osobiste braki i niepowodzenia, narzekają na czynniki zewnętrzne, zamiast koncentrować się na tym, jak osiągnąć sukces. W obliczu trudności podejmują mały wysiłek i szybko się poddają, gdyż posiadają słabą wiarę we własne zdolności. Są też bardziej narażone na lęk, poczucie bezradności, duże nasilenie smutku czy przygnębienia ${ }^{15}$.

W kolejnej części artykułu przedstawiono wyniki analiz wywiadów indywidualnych ze studentami o wysokim i niskim poczuciu własnej skuteczności na temat samodzielnego uczenia się.

\section{Obraz samodzielnego uczenia się studentów o niskim i wysokim poczuciu własnej skuteczności}

Pierwszy etap badań pozwolił na wyłonienie dwóch grup studentów, różniących się znacząco pod względem poziomu poczucia własnej skuteczności. Do dalszych badań, prowadzonych za pomocą wywiadu, zaproszono e-mailowo lub osobiście wszystkich respondentów, którzy uzyskali niski i wysoki wynik na skali GSES. W rezultacie, na zaproszenie odpowiedziało i zgody na wywiad udzieliło 24 studentów o niskim i 30 studentów o wysokim poczuciu własnej skuteczności. W grupie tej znalazły się osoby realizu-

${ }^{14}$ Zob. np. E.A. Locke, G.P. Latham, A theory of goal setting; N. Ogińska-Bulik, Z. Juczyński, Osobowość, stres a zdrowie; A. Bańka, Poczucie samoskuteczności. Konstrukcja i struktura czynnikowa Skali Poczucia Skuteczności w Karierze Międzynarodowej, Poznań - Warszawa 2016, s. 10.

${ }^{15}$ R. Schwarzer, R. Fuchs, Self-efficacy and Health Behaviours, s. 163-196. 
jące studia zarówno w trybie stacjonarnym, jak i niestacjonarnym. Pozostali studenci nie byli zainteresowani udziałem $w$ badaniach lub rezygnowali po wyrażeniu wstępnej zgody na wywiad. Wywiady miały charakter indywidualny; z każdą osobą ustalono dogodny dla niej termin, który nierzadko z różnych przyczyn ulegał modyfikacji. Ten etap badań wymagał dużego zaangażowania i dyspozycyjności ze strony badacza, stąd jego realizacja zajęła stosunkowo dużo czasu. Jak wcześniej wspomniano, wywiady miały charakter częściowo skategoryzowany, co dawało prowadzącej możliwie duży zakres swobody w zadawaniu pytań. Były realizowane na podstawie kwestionariusza wywiadu, który zawierał wprawdzie listę podstawowych pytań, głównie o charakterze otwartym, ale w trakcie wywiadu zadawano je w różny sposób i w różnej kolejności, zależnie od wypowiedzi respondenta, a także zadawano dodatkowo pytania nie mieszczące się w kwestionariuszu wywiadu. Wywiady dotyczyły samodzielnego uczenia się - tematu bliskiego uczestnikom badań, głównie ze względu na ich własne doświadczenia w tym zakresie. Można założyć, że dysponowali oni "prawdziwą wiedzą" o przedmiocie i wykazywali chęć dzielenia się nią z osobą słuchającą, która ze swej strony starała się wiernie zrozumieć przekazywane informacje oraz zadbać, aby wywiad stawał się procesem interakcji, czyli wzajemnego oddziaływania osoby go prowadzącej i respondenta ${ }^{16}$. Pytania zadawane badanym koncentrowały się wokół rozumienia przez nich pojęcia „uczenie się", przebiegu ich samodzielnego uczenia się oraz oceny efektywności tego procesu. Wszystkie wywiady, po uprzednio uzyskanej zgodzie, były nagrywane, a następnie dokonano ich transkrypcji. Za wartościowe uznano także zapisywanie, po każdym przeprowadzonym wywiadzie, własnych spostrzeżeń na temat ogólnej atmosfery panującej podczas wywiadu, a także innych ważnych kwestii, mogących mieć znaczenie dla zrozumienia i interpretacji uzyskanego materiału badawczego. Praca nad protokołami z wywiadów przebiegała zgodnie z metodą analizy treści; po etapie selekcji i porządkowania danych wyróżniono $\mathrm{w}$ tekstach kategorie analityczne, nasycone wskaźnikami i kontekstem, którym przypisano odpowiednie kody analityczne. Uwzględniono przy tym dygresje i fragmenty wypowiedzi wykraczające poza problem badań. W obrębie kategorii analitycznych poszukiwano pewnych regularności, prawidłowości oraz powiązań pomiędzy poszczególnymi sekwencjami danych, właściwych dla zbiorowości, a nie tylko dla jednostkowych przypadków ${ }^{17}$, a następnie próbowano wydobyć podobieństwa i różnice $\mathrm{w}$ wypowiedziach studentów zaklasyfikowanych do różnych grup problemowych, dokonać ich zestawienia w celu sformułowania

${ }^{16}$ M. Łobocki, Metody i techniki badań pedagogicznych, s. 262.

${ }_{17}$ Zob. np. D. Bertaux, Funkcje wypowiedzi biograficznej w procesie badawczym, [w:] Metoda biograficzna w socjologii, red. J. Włodarek, M. Ziółkowski, Warszawa - Poznań 1990, s. 77-78. 
uogólnień, mogących mieć znaczenie dla problematyki badań. W dalszej części artykułu przedstawiono efekt tych analiz.

W obrazie samodzielnego uczenia się studentów o różnym poziomie poczucia własnej skuteczności nie zaobserwowano znaczących różnic w sposobie definiowania pojęcia uczenie się. W obu grupach zdecydowanie dominuje potoczne i powierzchowne rozumienie tego terminu. Jest on generalnie utożsamiany z przyswajaniem nowej wiedzy i nabywaniem określonych umiejętności, często w sytuacjach związanych z procesem studiowania - w sesji zaliczeniowej i egzaminacyjnej. Należy przy tym zauważyć, że w grupie badanych o niskim poczuciu własnej skuteczności zaobserwowano więcej wypowiedzi identyfikujących uczenie się z: „przykrym obowiązkiem”, , koniecznością", "przymusem”. Dla ilustracji posłużymy się dwoma fragmentami wypowiedzi uczestników badań:

Podjętam decyzję, żeby studiować, więc muszę się uczyć, zwtaszcza że płace za studia, ale samodzielne uczenie się nie należy do przyjemnych zajęć.

Generalnie nie lubię się uczyć i robię to tylko przed egzaminami, chcę skończyć studia i mieć ciekawa prace (...), siedzenie i wkuwanie suchej teorii jest męczace inudne.

W obu badanych grupach wystąpiła ponadto tendencja do rozdzielania uczenia się wynikającego z obowiązków szkolnych od uczenia się (w znaczeniu poszerzania wiedzy) dla siebie, dla przyjemności, w ramach rozwijania własnych zainteresowań. Tendencja ta była jednak bardziej widoczna w grupie studentów o wysokim poczuciu własnej skuteczności (13 odniesień do 5). Ponadto, warto podkreślić, że tylko w tej grupie pojawiło się, reprezentowane przez cztery osoby, szersze rozumienie uczenia się, zbliżone do pożądanej w kształceniu akademickim idei uczenia się głębokiego, wynikającego $\mathrm{z}$ autonomicznych potrzeb jednostki, opartego na zaangażowaniu i osobistej refleksji. Dla obu grup charakterystyczne okazało się natomiast indywidualistyczne podejście do procesu uczenia się, marginalizowanie jego społecznych aspektów oraz poczucie odpowiedzialności za jego efekty, choć studenci o niskim poczuciu własnej skuteczności znacznie częściej przywoływali w swoich wypowiedziach czynniki zewnętrzne zaburzające ten proces. Zarówno osoby o niskim, jak i wysokim poczuciu własnej skuteczności przypisywały uczeniu się dużą wartość, uznając je za środek niezbędny do realizacji celów życiowych, zawodowych, ułatwiający funkcjonowanie „w zmieniającej się wciąż rzeczywistości”, „”w globalnym świecie”, pozwalający na rozwijanie własnych zainteresowań i pasji, czy też urzeczywistnianie celów osobotwórczych. Akceptowali również konieczność ustawicznego uczenia się i często odwoływali się do tej idei w odniesieniach do specyfiki pracy w zawodzie nauczyciela: 
Wybrałam zawód, który będzie ode mnie wymagat ciagłej aktywności, aby awansować będę musiała stale się dokształcać na różnych kursach, studiach podyplomowych. Moja mama pracuje w przedszkolu, więc zdaje sobie sprawe ile czeka mnie pracy (studentka o niskim poczuciu własnej skuteczności).

Jedynie $\mathrm{w}$ dwóch przypadkach, reprezentowanych przez studentów o wysokim poczuciu własnej skuteczności, uczenie się było traktowane jako wartość autoteliczna, będąca celem samym w sobie:

...nie wyobrażam sobie, że moge przestać się uczyć, po prostu lubię zdobywać nowa wiedzę i rozwijać umiejętności, nie tylko te wymagane na studiach (...) dzień bez nauki, to dla mnie czas stracony.

Sposób rozumienia pojęcia uczenie się oraz nadawanie mu określonej wartości wyznacza w pewien sposób myślenie o edukacji, rodzaj i funkcje czynności podejmowanych przez uczestników procesów edukacyjnych, a także rolę, jaką osoby uczące się przypisują sobie samym w tym procesie. Aktywność respondentów związana z samodzielnym uczeniem się okazała się zróżnicowana i stanowiła najszerzej rozwijany $w$ wywiadach wątek, bez względu na poziom poczucia własnej skuteczności. Analiza materiału badawczego, w postaci protokołów z wywiadów, wykazała, że w obu grupach problemowych dominują mało skuteczne techniki uczenia się, zatem często wysiłek włożony w naukę własną nie przekłada się na oczekiwane rezultaty ${ }^{18}$. Można do nich zaliczyć przede wszystkim wielokrotne czytanie, uczenie się skomasowane, a także podkreślanie. Wielokrotne czytanie tej samej treści, w postaci notatek czy podręcznika, nie prowadzi do trwałego zapamiętywania wiedzy, zabiera dużo czasu, a dodatkowo łączy się z mimowolnym oszukiwaniem samego siebie, gdyż po kilkukrotnym zaznajomieniu się z tekstem powstaje mylne wrażenie opanowania jego treści ${ }^{19}$. Mało efektywne jest też uczenie się skomasowane, które polega na intensywnym uczeniu się dwa, trzy dni przed zaliczeniem ćwiczeń bądź egzaminem oraz wielokrotnym powtarzaniem tych samych treści kształcenia. Badania dowodzą, że takie podejście w szyb-

${ }^{18}$ J. Dunlosky i in., Improving Students' Learning with Effective Learning Techniques: Promising Directions from Cognitive and Educational Psychology, Psychological Science in the Public Interest, 2013, 14, 1, s. 4-58.

${ }_{19}$ Zob. wyniki badań prowadzonych przez A.A. Callendera, M.A. McDaniela oraz J.D. Karpicke, A.C. Butler, H.I. Roediger (A.A. Callender, M.A. McDaniel, Te limited benefts of rereading educational texts, Contemporary Educational Psychology, 2009, 34(1), s. 30-41; J.D. Karpicke, A.C. Butler, H.I. Roediger, Metacognitive strategies in studentlearning: Do students practise retrieval when they study on their own? Memory, 2009, 17(4), s. 471-479) oraz T. Gilovich, N. Epley, K. Hanko, Shallow Toughts About the Self: Te Automatic Components of Self-Assessment. [w:] Te Self in Social Judgment. Studies in Self and Identity, red. M.D. Alicke, D.A. Dunning, J.I. Krueger, Psychology Press, New York 2005, s. 77-132. 
kim tempie przeciąża umysł i prowadzi do słabszego zapamiętywania niż na przykład rozkładanie ćwiczeń w czasie i uwzględnianie w planie nauki kilku dziedzin wiedzy naraz ${ }^{20}$. Podobnie podkreślanie podczas czytania powinno stanowić raczej punkt wyjścia do dalszego opracowywania poznawanego materiału. Samo podkreślanie może ograniczać rozumienie przeczytanych treści, gdyż uczeń koncentrując się na konkretnych fragmentach, zapomina często o poszukiwaniu powiązań między nimi. Kolejne mało skuteczne techniki, przywoływane stosunkowo rzadko przez reprezentantów obu grup, to podsumowywanie, czyli dokonywanie $\mathrm{w}$ formie pisemnej parafraz najważniejszych idei, zawartych w tekście ${ }^{21}$ oraz - dające krótkotrwałe efekty - zapamiętywanie słów-kluczy i tworzenie obrazów umysłowych reprezentujących przyswajane treści. Warto dodać, że osoby rozdzielające $\mathrm{w}$ swoim myśleniu uczenie się obowiązkowe od uczenia się dla siebie, dla przyjemności, w ramach rozwijania własnych zainteresowań i pasji, wskazywali też inne sposoby uczenia się - na przykład technikę prób i błędów (malowanie na szkle, haftowanie), korzystanie z pomocy sprawdzonych autorytetów (instruktorów), czy też pomocy rówieśniczej. W wypowiedziach studentów szerzej rozumiejących pojęcie uczenia się można odnaleźć dodatkowo wątki związane z pracą nad własnym rozwojem ${ }^{22}$. Sposoby uczenia się badanych wynikają w dużej mierze z dotychczasowych "doświadczeń szkolnych”, „własnych starań związanych z próbami wypracowania określonego sposobu pracy” i nierzadko z zaleceń nauczycieli, rodziców, starszego rodzeństwa, kolegów, które $w$ dużej mierze oparte są na błędnych intuicyjnych przekonaniach o skuteczności konkretnych technik uczenia $\operatorname{się}^{23}$.

Analiza uzyskanego materiału badawczego wykazała brak znaczących różnic pomiędzy porównywanymi grupami w zakresie stosowanych sposobów uczenia się, jednak można zauważyć, że studenci o wysokim poczuciu własnej skuteczności używają nieco liczniejszych strategii uczenia się. Wydają się też bardziej zainteresowani poszukiwaniem nowych technik uczenia się, brakuje im jednak czasu, a niekiedy siły woli, aby ,je przetestować" w praktyce. Najbardziej znaczące różnice pomiędzy grupami zaznaczyły się natomiast $\mathrm{w}$ stopniu zaangażowania w naukę własną. Badani o wysokim poczuciu własnej skuteczności preferują znacznie częściej uczenie się systematyczne w toku studiów, poświęcając dużo czasu na samodzielną naukę i jej

${ }^{20}$ N.J. Cepeda i in., Distributed practice in verbal recall tasks: A review and quantitative synthesis, Psychological Bulletin, 2006, 132(3), s. 354-380.

${ }^{21}$ R.R. Gurung, How Do Students Really Study (and Does It Matter)? Teaching of Psychology, 2005, 32(4), s. 239-241.

${ }^{22}$ Por. V. Rodek, Learning and its Effectiveness in Students' Self - reflection, The New Educational Review, 2019, 55, 1, s. 112-120.

${ }^{23}$ Zob. J. Dunlosky i in., Improving Students' Learning with Effective Learning Techniques, s. $4-58$. 
optymalne zaplanowanie, zwłaszcza w zakresie rozkładania zadań w czasie. Dodatkowo charakteryzuje ich wytrwałość w uczeniu się, konsekwencja, umiejętność koncentracji na dłuższych okresach nauki, a także wysokie poczucie odpowiedzialności za własny proces uczenia się i osiągane wyniki:

Jak wyglada moje uczenie się ...no...chyba moge powiedzieć, że jestem systematyczna i potrafie się zorganizować, zwłaszcza przed sesją umiem rozłożyć sobie nauke, żeby nie uczyć się wszystkiego naraz (...) i wie Pani Profesor, ja to moge uczyć sie caty dzień - ucze sie, jem, chwila relaksu, ale bez telefonu, bo jak bym się zajęta telefonem, to czas mi ucieka, więc inny odpoczynek, ale krótki $i$ znów się uczę i idę spać. A kolejnego dnia od nowa i to daje efekty. Tak myśle.

Tylko ode mnie zależy, jakie będe miała oceny, nikt mnie nie zmuszat, żeby studiować (...) próbuje sensownie rozłożyć sobie nauke, żeby starczyło mi sit. Przed zaliczeniami i egzaminami inne rzeczy odkładam na bok. Jestem tylko ja i wiedza, która muszę zapamiętać.

Z kolei, studenci o niskim poczuciu własnej skuteczności wkładają zdecydowanie mniej wysiłku w proces samodzielnego uczenia się, ich praca jest często niesystematyczna, „epizodyczna” - tuż przed egzaminem czy też zaliczeniem $z$ danego przedmiotu. W analizowanej grupie uwidoczniły się przede wszystkim problemy z planowaniem własnego działania tak, aby nie „odkładać wszystkiego na ostatnią chwilę" oraz trudności z dłuższym skupieniem uwagi i „mobilizacją do uczenia się”. Silniej zaznaczyła się też tendencja do podporządkowania własnej aktywności poznawczej czynnikom zewnętrznym, zarówno ułatwiającym, jak i utrudniającym uczenie się. Ponadto, wielu badanych wskazywało na problemy z trwałym zapamiętaniem wiedzy, głównie z powodu „przeciążonego programu kształcenia na studiach". Nieco inny obraz zaangażowania w uczenie się można odnaleźć w grupie osób, które w swoim myśleniu rozdzielają uczenie się w ramach obowiązków szkolnych od uczenia się dla siebie, dla własnej przyjemności. Ich uczenie się na studiach jest często poprawne, mniej lub bardziej systematyczne, oparte na wypełnianiu podstawowych obowiązków związanych z rolą studenta. Wprawdzie osoby te zaliczają przedmioty, zdają egzaminy, ale w pełni angażują się tylko w to, co ich interesuje i jest związane $\mathrm{z}$ rozwijaniem własnych zainteresowań i pasji:

...dla siebie moge uczyć się wiele godzin; caty swój wolny czas, poza studiami, poświęcam na naukę tańca;

jeśli jakieś zagadnienie ze studiów mnie zainteresuje, to jestem w stanie wiele zrobić, aby je sama zgłębić; 
...zawsze miałam poczucie obowiazku, więc nie wyobrażam sobie, abym miała zawalić studia, ale uczę się stosujac strategię na skróty - tylko wtedy, gdy jest to konieczne. Caty swój czas poświęcam swojej pasji ...tu jest moje myślenie, mój umyst, moje serce.

Interesująco przedstawiały się także wypowiedzi badanych na temat efektów nauki własnej. Generalnie przeważały ostrożne sądy, typu:

jest nieźle, ale mogłoby być lepiej;

mogłabym więcej dać z siebie;

nauka samodzielna to trudna praca, jestem zadowolona $z$ siebie... tzn. w miare, bo powinnam mieć wyższe wyniki.

W grupie osób o niskim poczuciu skuteczności zaobserwowano jednak bardziej krytyczne podejście do oceny przebiegu i efektywności własnego uczenia się. Zwłaszcza studenci uczący się niesystematycznie wydają się świadomi niewielkiej skuteczności nauki własnej, głównie ze względu na brak owej systematyczności. Pomimo tendencji do akcentowania czynników zewnętrznych, warunkujących ich aktywność poznawczą, za brak systematyczności w uczeniu się obwiniają głównie siebie, wskazując na "lenistwo", "niedostatki w koncentracji uwagi”, ,męczliwość”, ,słabą wolę", , brak wytrwałości". Co ciekawe, pomimo odczuwanej potrzeby zmian w organizacji i przebiegu własnego uczenia się, podjęcia wysiłku pracy nad sobą, wiele osób przyznaje się do poczucia bezradności, przekonania, że „nie da się niczego zmienić”. Zdecydowanie bardziej pozytywne sądy na temat skuteczności nauki własnej wyrazili studenci o wysokim uogólnionym poczuciu własnej skuteczności, w tym osoby mocno zaangażowane w rozwijanie swoich zainteresowań i pasji. W ich wypowiedziach można odnaleźć satysfakcję i zadowolenie z siebie, wynikające $\mathrm{z}$ faktu "poradzenia sobie w trudnym okresie sesji", poczucie, że „zrobiło się wszystko, aby się nauczyć”, ale też nadzieję, że po zdaniu wszystkich egzaminów „nareszcie będzie można poświęcić czas na własne zainteresowania i przyjemności”.

Na zakończenie zaprezentowano - w sposób syntetyczny - najważniejsze wyniki i wnioski.

\section{Zakończenie - próba rekapitulacji}

Przedstawione w niniejszym artykule analizy doprowadziły do sformułowania pewnych następujących uogólnień.

1. W badanej grupie studentów dominuje przeciętny i wysoki poziom uogólnionego poczucia własnej skuteczności, jednak znaczący odsetek osób uzyskało niski wynik w tym zakresie. Przyczyn takiego stanu rzeczy może 
być wiele. Na ogół uważa się, że lepsze poczucie własnej skuteczności nabywa się poprzez: (1) bezpośrednie doświadczenie w wykonywaniu zadań i czynności; (2) doświadczenie zastępcze związane z obserwacją innych; (3) perswazje słowne, takie jak: sugestia, namawianie, zachęcanie, instruowanie; (4) pobudzenie emocjonalne; (5) okoliczności sytuacyjne ${ }^{24}$. Z edukacyjnego punktu widzenia, model dydaktyki wdrożeniowej, realizowany w polskich szkołach, preferujący kierowniczą rolę nauczyciela, receptywne metody nauczania i aktywność kierowaną uczniów ${ }^{25}$, nie sprzyja rozwojowi poczucia własnej skuteczności. W procesie kształcenia uczeń ma małe szanse na zdobywanie doświadczeń samodzielnego inicjowania aktywności i realizowania własnych dążeń. Częste ograniczanie samodzielności działań dziecka, nadmierne ich kontrolowanie i korygowanie powoduje, że nabywa ono przekonania o braku własnego wpływu na efekty działań, ponieważ znajdują się one poza jego kontrolą. W związku z tym, dziecko przestaje czuć się sprawcą uzyskiwanych rezultatów, upatrując przyczyn swych sukcesów głównie w czynnikach zewnętrznych ${ }^{26}$. Sytuacji nie poprawia funkcjonujące wśród nauczycieli przekonanie o szkodliwości błędów w nauczaniu i wynikające z niego obawy, że dziecko popełniające błędy utrwali niewłaściwy wzorzec postępowania. Tymczasem, badania prowadzone nad tym zagadnieniem wykazały, że błędy stanowią integralną część wysiłku, który jednostka wkłada w opanowanie konkretnej treści ${ }^{27}$. Dzieci dysponujące wiedzą na temat związku nauki z popełnianiem błędów znacząco częściej podejmują nowe wyzwania i starają się pokonywać trudności w procesie uczenia się. Okazuje się, że uczniowie osiągają znacznie lepsze wyniki, jeśli tworzy się im środowisko, w którym mogą się zmagać z trudnościami ${ }^{28}$.

2. Przyjęta $w$ badaniach zmienna - uogólnione poczucie własnej skuteczności różnicuje obraz samodzielnego uczenia się studentów, głównie w zakresie wielości stosowanych strategii uczenia się oraz stopnia zaangażowania w naukę własną. Wysoki poziom poczucia własnej skuteczności wydaje się mieć związek z systematycznością, wytrwałością w uczeniu się, konsekwencją, umiejętnością koncentracji na dłuższych okresach nauki, a także z umiejętnościami planowania i organizacji własnego procesu uczenia się. Uzyskane wyniki znajdują swoje uzasadnienie w świetle motywacyjnego znaczenia poczucia własnej skuteczności. W procesie motywacji chodzi o wybór sytuacji, preferencji dla określonych czynności i sformułowanie zamiaru, w tym

${ }^{24}$ A. Bandura, Self-efcacy: The exercise of control, New York 1997.

${ }^{25}$ Zob. D. Klus-Stańska, Paradygmaty dydaktyki. Myśleć teorią o praktyce, Warszawa 2018.

${ }^{26}$ V. Rodek, Stan i uwarunkowania autoedukacji studentów, Katowice 2014, s. 103-104.

27 B.J. Huelser, J. Metcalfe, Making related errors facilitates learning, but learners do not know it, Memory \& Cognition, 2012, 40(4), s. 514-527.

${ }^{28}$ F. Autin, J. Croizet, Improving working memory efciency by reframing metacognitive interpretation of task difculty, Journal of Experimental Psychology: General, 2012, 141(4), s. 610-618. 
przypadku zamiaru uczenia się. W procesie wolicjonalnym następuje zmiana intencji na rzeczywiste działanie i jego podtrzymywanie, pomimo różnych przeciwności. Przekonanie jednostki, że jest w stanie zrealizować zamiar okazuje się rozstrzygające dla przejścia z fazy motywacyjnej do fazy działania ${ }^{29}$. Spostrzegany brak własnej skuteczności może zdecydowanie obniżyć potencjał motywacyjny odnoszący się do pożądanego wyniku działania. Zainicjowanie działania wymaga odpowiedniej siły (wysiłku), zaś podtrzymywanie podjętego działania pomimo różnych przeciwności musi być wspierane wytrwałością. Im silniejsze poczucie własnej skuteczności i związane z nim oczekiwanie, tym większe przekonanie o możliwości osiągnięcia przez siebie dobrych wyników, trwałych skutków oraz konsekwentnego - mimo przeszkód - podtrzymywania działań prowadzących do celu ${ }^{30}$. W grupie studentów o niskim poziomie poczucia skuteczności największe problemy rozpoznano w fazie działania. Dotyczyły one umiejętności rozkładania zadań w czasie, systematycznej pracy i wytrwałości w uczeniu się. Pomimo prawidłowej identyfikacji tych problemów oraz krytycznej oceny efektywności nauki własnej, wielu studentów nie podejmuje działań w celu zmiany istniejącego, niekorzystnego stanu rzeczy. Być może brakuje im wiary, że zmiana jest możliwa, ale też dotychczasowe doświadczenia związane ze studiowaniem utwierdzają ich w przeświadczeniu, że pomimo słabego zaangażowania $\mathrm{w}$ proces samodzielnego uczenia się i tak osiągną pozytywne wyniki - zaliczą przedmioty, zdadzą egzaminy, jeśli nie w pierwszym, to w drugim terminie.

3. Przyjęta zmienna - uogólnione poczucie własnej skuteczności nie różnicuje natomiast, $\mathrm{w}$ znaczącym stopniu, sposobu rozumienia przez studentów pojęcia uczenie się, przypisywania mu wartości oraz stosowania określonych technik uczenia się. W badanej grupie dominuje uczenie się powierzchowne, w którym uczeń jest raczej biernym odbiorcą, oczekującym informacji, gotowych wniosków, odpowiedzi na pytania i wykorzystującym mało skuteczne techniki uczenia się, w efekcie czego włożony przez niego wysiłek nie przekłada się na oczekiwane rezultaty. Ponadto, uczenie się jest traktowane utylitarnie, jako środek umożliwiający realizację celów życiowych, zawodowych, związanych z własnymi zainteresowaniami, rzadko - jako wartość sama w sobie. Uzyskane wyniki wpisują się w dyskusje wokół problemu wzrastającego stopnia skolaryzacji na poziomie wyższym ${ }^{31}$. Uczynienie studiów powszechnymi pro-

29 Z. Juczyński, A. Juczyński, "Chcieć to móc”, czyli o znaczeniu poczucia własnej skuteczności w modyfikacji zachowań zwiąanych z piciem alkoholu, Alkoholizm i Narkomania, 2012, 2, s. $215-227$.

30 A. Bandura, Health promotion by social-cognitive means, Health Education \& Behavior, 2004, 2, s. 143-164.

31 Zob. np. U. Ostrowska, Aksjologiczne aspekty upowszechnienia wyższego wykształcenia w spoŁeczeństwie informacyjnym/społeczeństwie wiedzy, Pedagogika Szkoły Wyższej, 2006, 29; K. Wenta, Sukces czy klęska w upowszechnianiu szkolnictwa wyższego, Pedagogika Szkoły Wyższej, 2006, 28. 
wadzi - zdaniem niektórych autorów - do „inflacji wykształcenia wyższego": im więcej osób posiada dane dobro, tym staje się ono mniej cenne ${ }^{32}$.

Zarysowane w niniejszym artykule wątki nie stanowią ostatecznych rozstrzygnięć, otwierają raczej pole do dalszych dociekań badawczych, na przykład nad samoregulacją w uczeniu się, powszechnie uprawianą kulturą studiowania, czy też mitami związanymi z uczeniem się.

\section{BIBLIOGRAFIA}

Autin F., Croizet J., Improving working memory efciency by reframing metacognitive interpretation of task difculty, Journal of Experimental Psychology: General, 2012, 141(4).

Bandura A., Self-efficacy. Toward a Unifying Theory of Behavioral Change, Psychological Review, 1977, 2.

Bandura A., Self-efcacy: The exercise of control, Freeman, New York 1997.

Bandura A., Health promotion by social-cognitive means, Health Education \& Behavior, 2004, 2.

Bandura A., Teoria społecznego uczenia się, Wydawnictwo Naukowe PWN, Warszawa 2007.

Bańka A., Poczucie samoskuteczności. Konstrukcja i struktura czynnikowa Skali Poczucia Skuteczności w Karierze Międzynarodowej, Stowarzyszenie Psychologia i Architektura, Poznań - Warszawa 2016.

Bertaux D., Funkcje wypowiedzi biograficznej w procesie badawczym, [w:] Metoda biograficzna w socjologii, red. J. Włodarek, M. Ziółkowski, PWN, Warszawa - Poznań 1990.

Borowicz R., Funkcjonowanie szkolnictwa wyższego w Polsce - trzy wymiary temporalne, [w:] Świat idei edukacyjnych, red. W. Szulakiewicz, Wydawnictwo Naukowe UMK, Toruń 2008.

Brzeziński J., Co zrobić, aby zniszczyć uniwersytet?, [w:] Świat idei edukacyjnych, red. W. Szulakiewicz, Wydawnictwo Naukowe UMK, Toruń 2008.

Callender A.A., McDaniel M.A., Te limited benefts of rereading educational texts, Contemporary Educational Psychology, 2009, 34(1).

Cepeda N.J., Pashler H., Vul E., Wixted J.T., Rohrer D., Distributed practice in verbal recall tasks: A review and quantitative synthesis, Psychological Bulletin, 2006, 132(3).

Chomczyńska-Rubacha M., Rubacha K., Test Poczucia Skuteczności. Opracowanie teoretyczne i psychometryczne Pracowni Narzędzi Badawczych Komitetu Nauk Pedagogicznych PAN, Przegląd Badań Edukacyjnych, 2013, 1, 16.

Dolińska-Zygmunt G., Podmiotowe uwarunkowania zachowań promujacych zdrowie, Wydawnictwo Psychologii PAN, Warszawa 2000.

Dunlosky J., Rawson K.A., Marsh E.J., Nathan M.J., Willingham D.T., Improving Students' Learning with Effective Learning Techniques: Promising Directions from Cognitive and Educational Psychology, Psychological Science in the Public Interest, 2013, 14, 1.

Gurung R.R., How Do Students Really Study (and Does It Matter)?Teaching of Psychology, 2005, 32(4).

Huelser B.J., Metcalfe J., Making related errors facilitates learning, but learners do not know it, Memory \& Cognition, 2012, 40(4).

${ }^{32}$ R. Borowicz, Funkcjonowanie szkolnictwa wyższego w Polsce - trzy wymiary temporalne, [w:] Świat idei edukacyjnych, red. W. Szulakiewicz, Torun 2008, s. 49; J. Brzeziński, Co zrobić, aby zniszczyć uniwersytet?, [w:] Tamże, s. 65-67; Z. Kwieciński, Dewiacyjne zmiany w środowisku akademickim. Patologie czy epidemia?, [w:] Tamże, s. 68. 
Juczyński Z., Poczucie własnej skuteczności - teoria i pomiar, Acta Universitatis Lodziensis Folia Psychologica, 2000, 4.

Juczyński Z., Skala Uogólnionej Własnej Skuteczności, Pracownia Testów Psychologicznych PTP, Warszawa 2009.

Juczyński Z., Juczyński A., "Chcieć to móc”, czyli o znaczeniu poczucia wtasnej skuteczności w modyfikacji zachowań związanych z piciem alkoholu, Alkoholizm i Narkomania, 2012, 2.

Juszczyk S., Badania ilościowe w naukach społecznych. Szkice metodologiczne, Wydawnictwo Śląskiej Wyższej Szkoły Zarządzania im. gen. J. Ziętka, Katowice 2005.

Karpicke J.D., Buter A.C., Roediger H.I., Metacognitive strategies in student learning: Do students practise retrieval when they study on their own? Memory, 2009, 17(4).

Klus-Stańska D., Paradygmaty dydaktyki. Myśleć teoria o praktyce, Wydawnictwo Naukowe PWN, Warszawa 2018.

Kwieciński Z., Dewiacyjne zmiany w środowisku akademickim. Patologie czy epidemia?, [w:] Świat idei edukacyjnych, red. W. Szulakiewicz, Wydawnictwo Naukowe UMK, Torun 2008.

Lewtak K., Smolińska J., Uogólnione poczucie własnej skuteczności a zachowania antyzdrowotne lekarzy rodzinnych na przykładzie palenia tytoniu, Przegląd Epidemiologiczny, 2011, 65.

Locke E.A., Latham G.P., A theory of goal setting and task performance, Prentice Hall, New York 1990.

Łobocki M., Metody i techniki badań pedagogicznych, Oficyna Wydawnicza Impuls, Kraków 2005.

Maddux J.E., Lewis J., Self-efficacy and adjustment. Basic principles and issues, [w:] Self-effica$c y$, adaptation and adjustment: theory, research and application, red. J.E. Maddux, Plenum Press, New York 1995.

Metoda biograficzna w socjologii, red. J. Włodarek, M. Ziółkowski, PWN, Warszawa - Poznań 1990.

Ogińska-Bulik N., Juczyński Z., Osobowość, stres a zdrowie, Wydawnictwo Difin, Warszawa 2008.

Ostrowska U., Aksjologiczne aspekty upowszechnienia wyższego wyksztatcenia w społeczeństwie informacyjnym/społeczeństwie wiedzy, Pedagogika Szkoły Wyższej, 2006, 29.

Palka S., Metodologia. Badania. Praktyka pedagogiczna, Gdańskie Wydawnictwo Psychologiczne, Gdańsk 2006.

Predicting Health Behaviour, red. M. Conner, P. Norman, Open University Press, Buckingham - Philadelphia 1996.

Rodek V., Stan i uwarunkowania autoedukacji studentów, Wydawnictwo Uniwersytetu Śląskiego, Katowice 2014.

Rodek V., Learning and its Effectiveness in Students' Self - reflection, The New Educational Review, 2019, 55, 1.

Rubacha K., Metodologia badań nad edukacja, Wydawnictwo Akademickie i Profesjonalne, Warszawa 2008.

Schwarzer R., Fuchs R., Self-efficacy and Health Behaviours, [w:] Predicting Health Behaviour, red. M. Conner, P. Norman, Open University Press, Buckingham - Philadelphia 1996.

Self-efficacy, adaptation and adjustment: theory, research and application, red. J.E. Maddux, Plenum Press, New York 1995.

Świat idei edukacyjnych, red. W. Szulakiewicz, Wydawnictwo Naukowe UMK, Torun 2008. Te Self in Social Judgment. Studies in Self and Identity, red. M.D. Alicke, D.A. Dunning, J.I. Krueger, Psychology Press, New York 2005.

Wenta K., Sukces czy klęska w upowszechnianiu szkolnictwa wyższego, Pedagogika Szkoły Wyższej, 2006, 28. 